International Journal of Biology, Pharmacy and Allied Sciences (IJBPAS) 'A Bridge Betuen Caboratory and QRendo' WwW.ibpas.com

HUMAN ENTERIC PATHOGENS ASSOCIATED WITH EDIBLE PLANT PARTS: INSIGHT INTO MOLECULAR ASPECTS

\title{
SAKSHI $^{1}$ AND INDU GAUR ${ }^{*}$
}

1: Cell And Molecular Biology Lab, Amity Institute Of Biotechnology, Amity University Uttar Pradesh, Sector 125, Gautam Buddha Nagar, Noida, U.P.- 201303

*Corresponding Author: Dr. Indu Gaur: E Mail: indugaur03@gmail.com; Phone: (91) 9871343498

Received $31^{\text {st }}$ March 2020; Revised 21 ${ }^{\text {st }}$ April 2020; Accepted $13^{\text {th }}$ July 2020; Available online $1^{\text {st }} J_{a n} 2021$

\section{https://doi.org/10.31032/IJBPAS/2021/10.1.5321}

ABSTRACT

The existence of human enteric pathogens (HEPs) on the edible parts is a well-known fact as evidenced by large number of outbreaks caused by them.HEPs have the ability to exist on plants even under unfavourable conditions by means of attachment, invasion and subsequent colonization. Plant microbiome of phyllo sphere and rhizosphere help the HEPs to expand, survive and exist on plants. They help in growth, occurrence and stress resilience. Some plants are also known to develop innate immune response against enteric pathogens to break their pathogen cycle.

In recent scenario, many foodborne diseases occurring all over the globe have been linked to contamination of leafy greens and fresh produce by enteric pathogens. Direct consumption of fresh vegetables and fruits including tomato, sprouts, lettuce, spinach etc. are the cause of food borne illnesses. Improper processing, preparation, and handling of food are also a major cause. Improper storage andtransportation of fresh produce from one country to another are also major causes of many outbreaks. The majority of research work hascentred on postharvest microbial infection as a main issue.Humansare at potent risk as the consumption of such contaminated plant parts as it is hazardous to human health. This review summarizes the updated information on the existence of HEPs on fresh produce and its subsequent impact on human health, as well as puts light on association of HEPs with plants through molecular and in silico studies.

Keywords: HEPs, fresh produce, innate immune response, food borne outbreaks, biofilms, in silicostudies 


\section{INTRODUCTION}

The word enteric means 'related to intestine'. Remaining intact in the stomach and get dissolved in the intestine is referred to as enteric. Enteric pathogens are the microbes that cause "enteric disease" [1]. The enteric disease is characterised by passing loose or unformed stools occurs three or more times in a day which is also called as diarrhoea and in addition, many intestinal infections can occur affecting the absorption of nutrients and their movement from small intestine to the blood supply [2]. It can also disrupt the absorptive and barrier function of intestine [3].

In recent years, the infection caused by enteric pathogens linked to fresh fruits and vegetables has arose a concern towards it. Mainly the food borne outbreaks caused by consuming lettuce, sprouts, spinach, radish, carrots etc. $[4,5,6,7,8]$. An in-depth study revealed that enteric pathogens survive in soil, water and, manure [9]. Fresh produce is contaminated during the harvesting process as well as cutting tools used during harvesting may contaminate the produce [9]. The accessibility and attainability of modern tools and techniques has led to the detailed study of HEPs colonization and survival on edible plant parts. Some bioinformatic and molecular tools have been used nowadays for advance study [10]. The main factor behind increasing risk of outbreaks is the harvesting, processing and distribution process of fresh produce. The factors on which the expansion, existence and survival of HEPs depend are environmental conditions, early or late fruit ripening, pre and post harvesting process, plant immune response development, resistance of enteric pathogens by plants and so on [9].

This review focuses and emphasizes on the sources of contamination through which enteric pathogens enter into leafy greens, their survival and existence strategies, biofilm matrix formation and molecular mechanisms of colonization. It also discusses genomic comparison between host plants and pathogens colonizing on them and, immune response of plants developed against such colonization.

\section{FOOD BORNE OUTBREAK CAUSED}

\section{BY HUMAN ENTERIC PATHOGENS}

The occurrence of two or more than two cases caused by the same disease resulting by the indigestion of same food is called as food borne disease outbreak. This can be detected on the basis of the epidemiological data as well as clinical information. The outbreak can be confirmed when the causal organism is known. Causal organism can be bacteria, virus, protozoa or helminths [11].

As the per the records (1980-2016), main causal agents for food borne outbreaks are Salmonella species, E. coli species, 
Yersinia species, Vibrio species, Listeria monocytogenes [12]. The outbreaks caused worldwide by HEPs are summarised in Table 1 [13, 14, 15]. Infection can be caused when these microbes invade and multiply in the intestinal tract and release toxin. The incubation period can last from few hours to days and may vary from one to another pathogen. Mode of subsequent transmission is usually from person to person through faecal-oral path [16].

\section{SOURCES OF CONTAMINATION}

There are two ways by which host plant is exposed to HEPs: direct and indirect method. The pathogens are shedded into the human faeces and then plants get exposed to enteric pathogens through direct contact with the faecal matter or indirect contact by contaminated irrigation water or soil or manure [9]. The factors that play important role in contamination of fresh fruits and vegetables with HEPs are contaminated irrigation water, contaminated seeds, untreated manure, bioaerosols and insect, fungi, nematode, protozoa as vectors [17]. Figure 1 summarises the various routes of contamination by HEPs.

Table 1: Outbreaks caused due to by HEP contaminated fresh produce

\begin{tabular}{|c|c|c|c|}
\hline YEAR & CAUSAL PATHOGEN & SOURCE & REMARKS \\
\hline 2020 & Listeria monocytogenes & Enoki Mushrooms & United States ( 36 cases) \\
\hline 2019 & $\begin{array}{l}\text { Salmonella javiana, } \\
\text { Salmonella Uganda, } \\
\text { Salmonella carrau }\end{array}$ & $\begin{array}{l}\text { Cut fruit, Fresh papayas, } \\
\text { Pre-cut melon }\end{array}$ & United States ( 383 cases) \\
\hline 2019 & E. coli $0157: H 7$ & $\begin{array}{l}\text { Sunflower chopped salad } \\
\text { kits, Romaine Lettuce }\end{array}$ & $\begin{array}{c}\text { United States (177), } \\
\text { Canada }\end{array}$ \\
\hline 2018 & $\begin{array}{c}\text { Salmonella adelaide, Salmonella } \\
\text { Montevideo, Salmonella typhimurium, } \\
\text { Salmonella entericaserotype Poona, } \\
\text { E. coli } 0157: \mathrm{H} 7\end{array}$ & $\begin{array}{c}\text { Pre-cut melon, Raw } \\
\text { sprouts, Dried Coconut, } \\
\text { Rice, } \\
\text { Romaine lettuce }\end{array}$ & $\begin{array}{l}\text { United States (101 cases), } \\
\text { France, Belgium, } \\
\text { Luxembourg ( } 32 \text { cases), } \\
\text { United states ( } 210 \text { cases) }\end{array}$ \\
\hline 2017 & E. coli 0157:H7, Salmonella anatum, & $\begin{array}{l}\text { Leafy Greens, Maradol } \\
\text { Papayas }\end{array}$ & United States (45 cases) \\
\hline 2016 & $\begin{array}{c}\text { Listeria monocytogenes, } \\
\text { Salmonella reading \& Salmonella } \\
\text { abony, } \text { E. coli } 0157\end{array}$ & $\begin{array}{c}\text { Frozen Vegetables, } \\
\text { Packaged Salads, Alfalfa } \\
\text { sprouts }\end{array}$ & United States (101 cases) \\
\hline 2015 & $\begin{array}{c}\text { Salmonella poona, Listeria } \\
\text { monocytogenes }\end{array}$ & Cucumber, Frozen Corn & $\begin{array}{c}\text { United States ( } 907 \text { cases), } \\
\text { Hungary ( } 32 \text { cases) }\end{array}$ \\
\hline 2014 & $\begin{array}{c}\text { Listeria monocytogenes, Salmonella } \\
\text { enteritidis, Salmonella Newport, } \\
\text { Salmonella agona, } \\
\text { E. coli O121, Salmonella agona }\end{array}$ & $\begin{array}{c}\text { Bean Sprouts, Caramel } \\
\text { Apples, Cucumber, Raw } \\
\text { Clover Sprouts, Cucumber } \\
\text { plant }\end{array}$ & $\begin{array}{c}\text { United States (449 cases), } \\
\text { Europe ( } 275 \text { cases), } \\
\text { Denmark, Europe (147 } \\
\text { cases) }\end{array}$ \\
\hline 2013 & E. coli O121, Salmonella saintpaul & $\begin{array}{c}\text { Frozen Food Products, } \\
\text { Cucumber }\end{array}$ & United States (119 cases) \\
\hline 2012 & $\begin{array}{c}\text { Salmonella braenderup, } E \text {. coli } \\
\text { O157:H7, E. coli } \mathrm{O} 26\end{array}$ & $\begin{array}{l}\text { Mangoes, Organic spinach } \\
\text { and Spring Mix blend, } \\
\text { Raw Clover Sprouts }\end{array}$ & United States (189 cases) \\
\hline 2011 & $\begin{array}{c}\text { E. coli O104:H4, } \\
\text { E. coli O157, Salmonella enteritidis, } \\
\text { Listeramonocytogenes }\end{array}$ & $\begin{array}{c}\text { Sprouts of fenugreek } \\
\text { seeds, Romaine lettuce, } \\
\text { Alfalfa and spicy sprouts, } \\
\text { Turkish pine nuts, } \\
\text { Cantaloupes } \\
\end{array}$ & $\begin{array}{l}\text { Germany ( } 3542 \text { cases), } \\
\text { United States ( } 325 \text { cases) }\end{array}$ \\
\hline
\end{tabular}




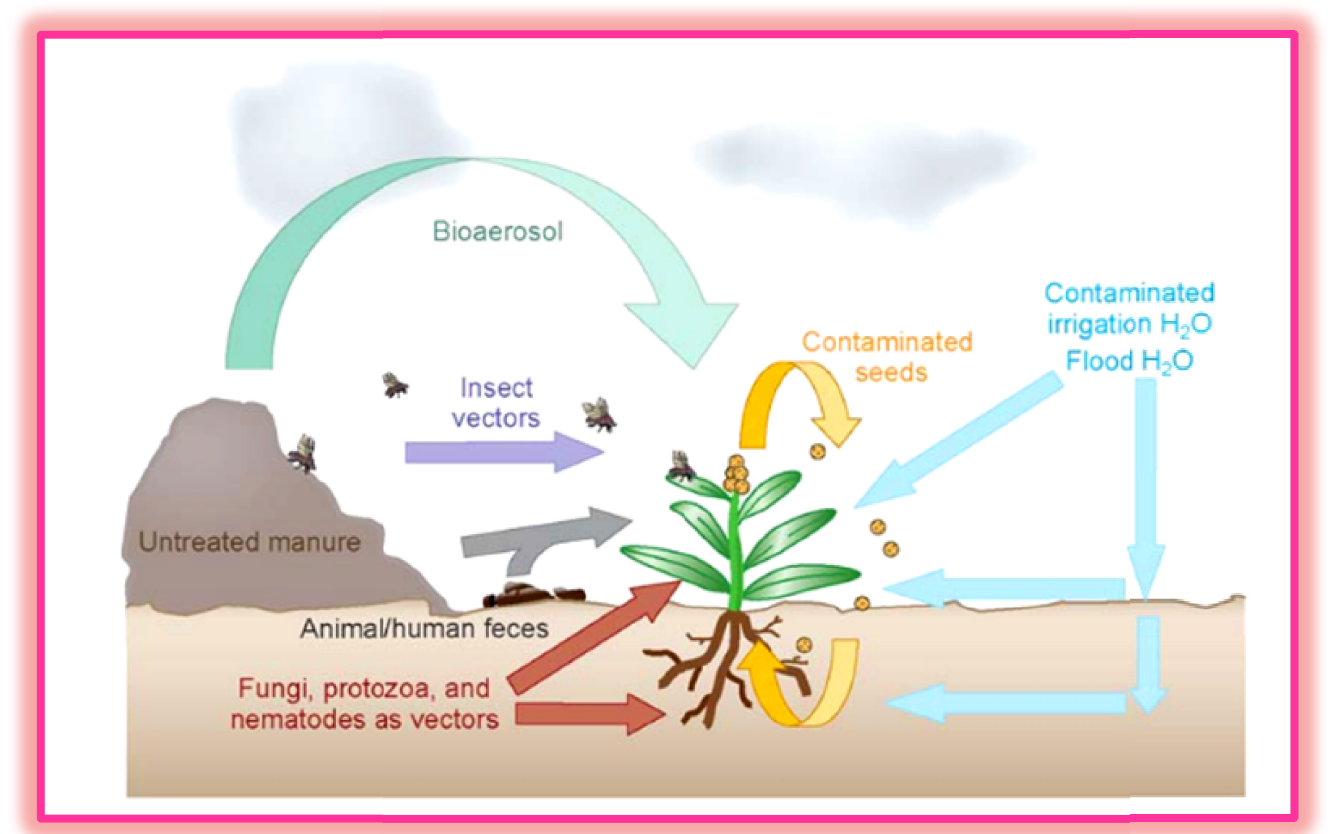

Figure 1: Contributing factors leading to the contamination of fresh produce and leafy greens in the agricultural fields

The enteric pathogens can gain entry into an agricultural field throughfarm yard dung based manure, compost and mixingsewage in the soilas shown in Figure 2 [18]. The main source of contamination is the faeces of animals. The food borne pathogens can survive in soil as soil plays an important role in transmission of disease caused by enteric pathogens $[\mathbf{1 9}, \mathbf{2 0}]$. The enteric pathogens are present in birds, cattle, deer, dogs, horse, sheep etc. These can be transmitted into the soil by faeces of the organism. The three types of soil in which existence can be examined are sandy soil, loamy soil and loamy sand soil [21]. The most optimal soil for the growth is sandy soil. In soil, temperature and moisture affects the survival of a pathogen. Low temperature and high moisture content is ideal for the pathogen survival [21]. The most common source by which HEPs are introduced into the soil is manure. They can be spread by rain, water current, and underground spring that contain contaminated material. The adhesion of enteric bacteria to the soil can be influenced by various factors like different type of soil type, texture of surface, surface charge and wettability [22]. Addition of pesticides to the field is also an important cause of contamination. The pathogen recovery was greater from the foliage infection caused by sprinkler irrigation in which water is applied to the field in way like rainfall as compared to drip irrigation [22].

Irrespective of the route, all enteric pathogens come in contact with the plant parts like leaves, stem, fruits and flowers of the plant and through this they enter the plant tissue leading to infiltration and colonization [23]. Major factors that affect 
the existence of enteric pathogens on plants are toxic chemicals released by certain plants, UV radiation and availability of micronutrients on plant surface inhabited by these pathogens [24]. Contamination of edible plant parts by HEPs leads to food safety hazard [25]. Once consumed by humans, contaminated fresh produce leads to disease development in them.

\section{MOLECULAR MECHANISM OF COLONIZATION OF HEPs ON PLANTS}

The multiplication, entry, growth and, survival of HEPs into host plant is called process of colonization. Plants can act as epiphytes, endophytes and thus play a significant role as primary host for colonization of HEPs. There are three steps involved in the process of colonization i.e. attachment, invasion and establishment as demonstrated in Figure 3 [26]. These pathogens haveability to bind to host specific receptors. This is attributed to a large number of adherence factorspresent in bacterialgenome. The enteric bacteria such as E. coli $0157: \mathrm{H} 7$ consist of protein/factors leading to fimbrial adhesion [27]. These factors are responsible for the recognition of glycosylation patterns in the host receptor proteins [28]. The host defence response is manipulated by pathogen through a common mechanism in which microbial effector protein is injected into host cell. This mechanism is known as TTSS i.e. type 3 secretion system which is a complex that acts as junction between host cell and pathogen [29, 30]. This junction mediates the secretion of pathogen associated effector proteins in host cell.

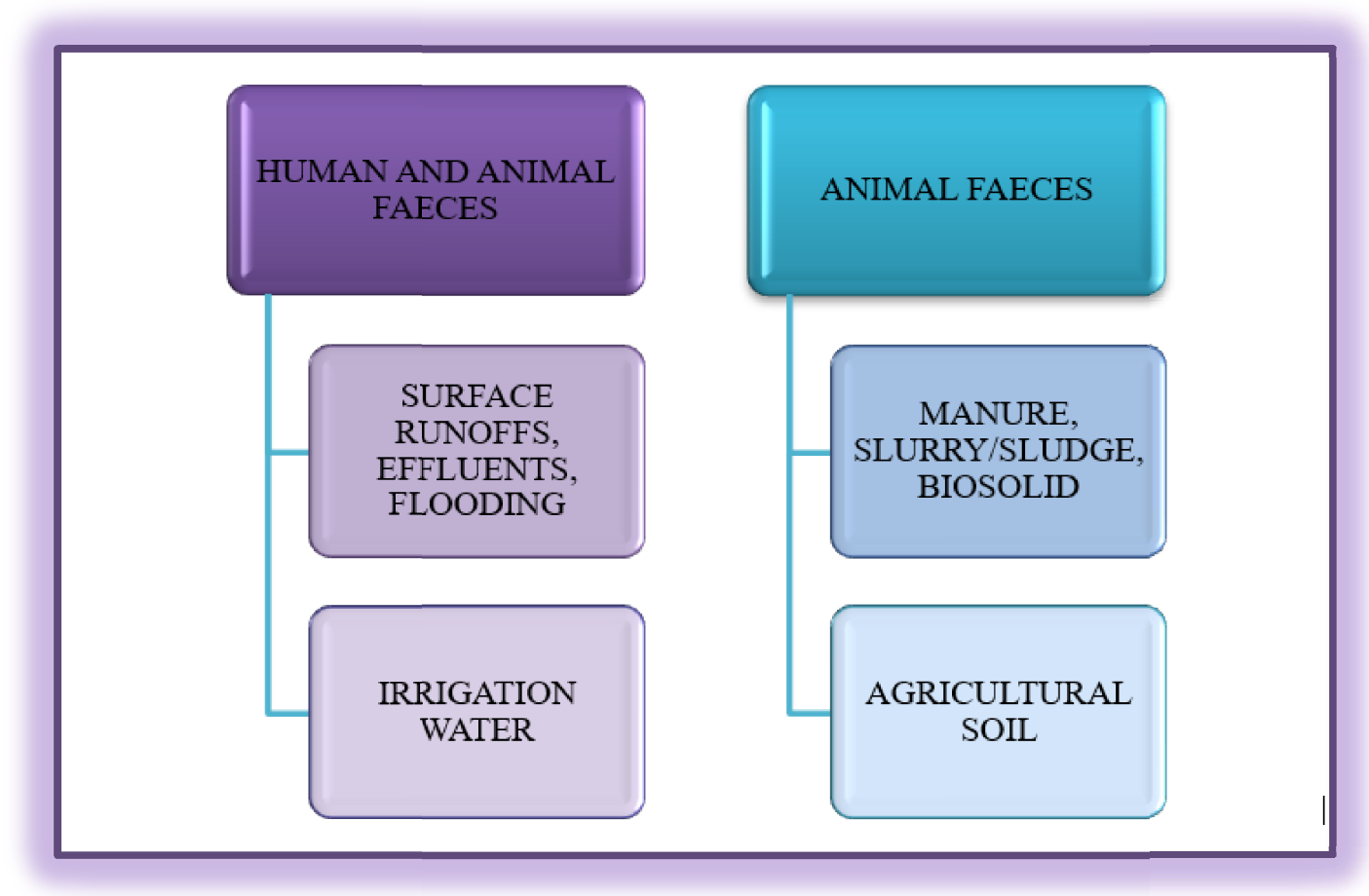

Figure 2: Different sources by which HEPs attacking fresh produce 


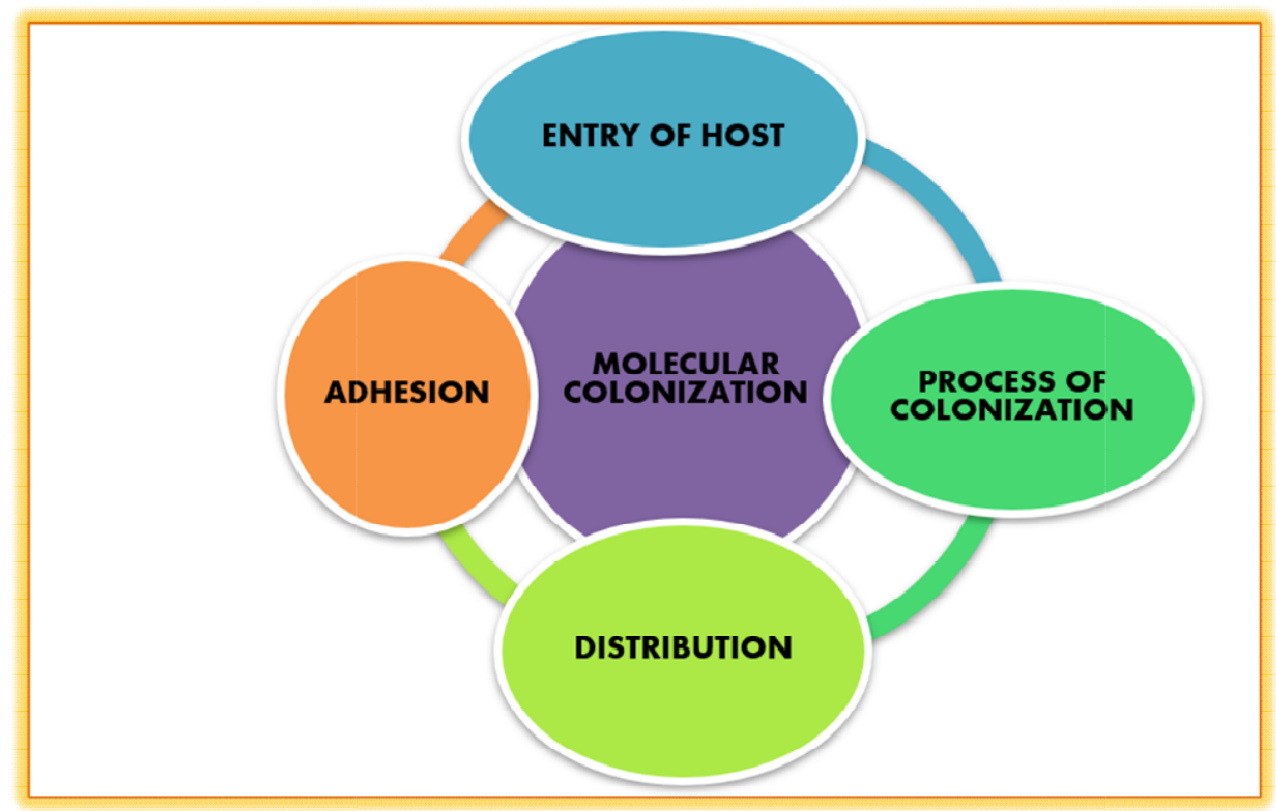

Figure 3: Cyclic process of Molecular Colonization

Flagella of E. coli O157:H7 seems to have similar mechanism to TTSS as utilized by plant pathogenic bacteria. Process of colonization by $E$. coli $\mathrm{O} 157: \mathrm{H} 7$ involves the binding of host cell to fimbriae, wherein the structural protein EspA plays critical role in mediating the host- pathogen interaction $[29,30,31]$. After binding to host cell, a pore is created in the membrane of the host cell and then translocation of Tir protein takes place. This Tir receptor recognises a bacterial adhesin known as intimin [29]. Binding of Tir receptor tointimin results inattachment and formation of $\operatorname{an}(\mathrm{A} / \mathrm{E})$ lesion denoting attaching and effacing lesions that denotes the close association between HEPs and host cell [31, 32]. In E. coli O157:H7, binding takes place with leaf epidermis followed by expression of TTSS, which requires the temperature of $37^{\circ} \mathrm{C}[33]$.

Table 2 shows the summarised form of different proteins, receptors present in HEPs and plants.

HecA, agglutinin like protein also plays a vital role in HEPs plant interaction [34]. Most HEPs invade the plant extracellularly in the apoplast. For this, pathogens require motility to invade the external surface as well as internal plant tissues. Enteric bacteria aim to abolish the plant innate immune defence system in order to establish themselves on plant surface. Plants recognize enteric pathogen in two steps. Firstly, PTI (Pattern triggered immunity) recognizes membrane bound receptor MAMPs (Microbe associated molecular pattern) /PAMPs (Pathogen associated molecular pattern) and secondly, plant resistance protein recognises the enteric pathogen effector protein which leads to Effector triggered immunity [35, 36]. 
S.enterica, Shigellaetc, invade the plant host by using TTSS for delivering effector protein [37]. Two variants of TTSS are encoded by Salmonella strain: SPI $1 \&$ SPI 2 which is Salmonella Pathogenicity Island 1 and 2 [38]. For macrophagial invasion there is requirement of SPI 1, whereas protection of growing bacterial colony and maintenance of internal vacuole is done by SPI 2 [39]. A cascade reaction is then triggered due to recognition of enteric pathogen by plant. Plant develops two types of responses as a result of such invasion: necrotrophic and biotrophic response. SA signalling pathway (salicylic acid) induces effector triggered immunity that recognises the presence of biotrophicpathogens $[\mathbf{4 0}, 41]$. Jasmonic acid (JA) or ethylene signalling pathway, induces effector triggered immunity in the presence of necrotrophic pathogens [41, 42].

The colonization of leafy parts by HEPs involves another molecular mechanism. The initial attachment or colonization occurs inrhizosphere as well as in the aerial parts of plants primarily stem, leaves and flowers. This initial attachment is mediated by curli, fimbriae and flagella associated factors/proteins [43]. From trichomes and root hairs, plant metabolites are released, which act as a chemical signal for movement of bacteria to the root surface [44]. Attachment to rhizosphere leads to biofilm formation [45]. Adaptation and survival of these pathogens leads to biofilm formation, whereas stress conditions including limitation of nutrients leads to upregulation of ycfR genes. $y c f R$ genes are the genes present mainly in E. coli species that performs mainly two functions i.e. stability in stressful condition and emergence of biofilm [46]. Protein synthesis process get downregulated and energy metabolism rate gets low during this process (Figure 4). In developing seedlings, E. coli O157:H7 colonizes the root junctions which are epidermal in nature [47].

For example, internalization of E. coli occurs when it is treated by the route of contaminated irrigation water and it is found on lettuce leaves. E. coli O157:H7 can also internalize radish sprouts through stomata and inside tissues of hypocotyls and cotyledons [48]. Salmonella strains have also been reported on lettuce plant [49]. Some S.enterica sero var colonize lettuce plant epiphytically and some endophytically (e.g. S. enteric sero var Dublin) [49]. Salmonella contaminate tomato plants through injured stems and flowers [50]. Inner cortex of root and root cells were colonized by Salmonella. Enteric bacteria are also able tocolonizecitrus plants in the root region as well as in xylem [51]. For example, orange is colonized by Salmonella and E. coli $\mathrm{O} 157: \mathrm{H} 7$ [51, 52]. 
Table 2: Receptors and proteins present in plants and enteric pathogens in response to each other

\begin{tabular}{|c|c|c|}
\hline PATHOGENS & $\begin{array}{c}\text { RECPTOR, PROTEINS IN } \\
\text { PATHOGENS }\end{array}$ & $\begin{array}{c}\text { RECEPTOR, GENE, PROTEININ } \\
\text { PLANTS }\end{array}$ \\
\hline E. coli O157:H7 & T3SS protein, Intimin protein, Tir \\
& receptor & NBS- LRR \\
\hline $\begin{array}{c}\text { Salmonella typhimurium } \\
\text { Salmonella Enteritidis }\end{array}$ & $\begin{array}{c}\text { T3SS -1 AND TTSS - 2, SP1 and } \\
\text { SP2, SP4, Effector proteins }\end{array}$ & MPKS3, MPK4,MPK6 \\
\hline E. coli & LPS, PRR & PR1 Gene, BGL2 promoter \\
\hline Salmonella species & FLS2 receptor & PR1, PR2, PR4, PR5 Gene \\
\hline
\end{tabular}

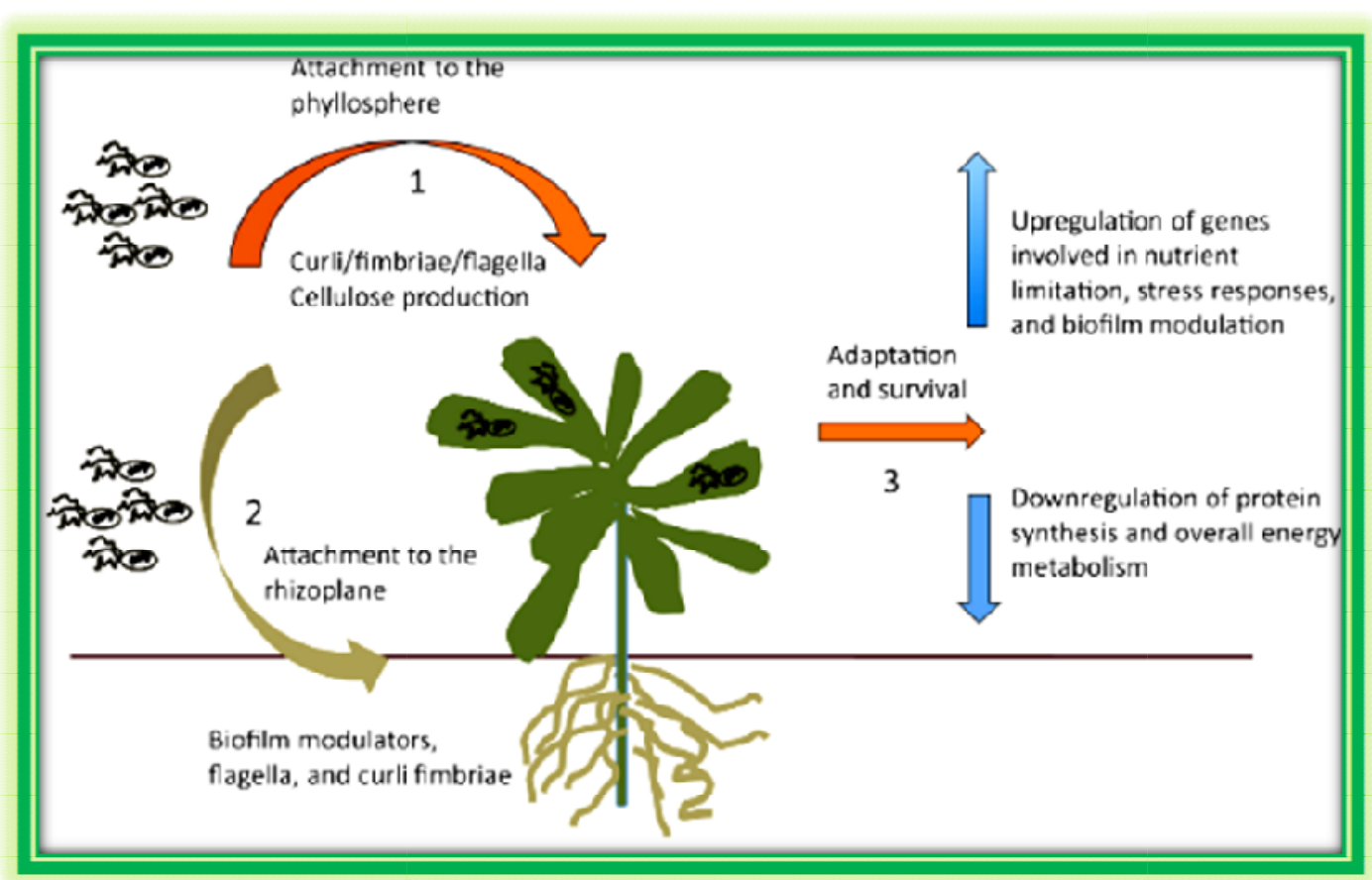

Figure 4: Molecular process of colonization by HEPs into leafy greens

\section{FORMATION OF BIOFILMS BY HEPs}

Bacterial biofilm is a structure that consists of community of cell of bacteria surrounded by polymeric matrix which is attached to the surface of colonization [53]. Steps involved in the formation of biofilm are landing of single free floating bacteria on the surface followed by accumulation of bacterial cells. As the dispersion ofbiofilms occurs, free floating bacteria get released leading to further spread and colonization. Biofilm consists of ninety seven percent water and thirty five percent dry weight of bacterial cells. When bacterial cell is attached to the host cell surface, formation of a slimy layer takes place. The enteric bacteria produce a variety of exopolysaccharides and proteinaceous components. This acts as an extracellular matrix meant for providing protection to the bacteria. This extracellular matrix has nucleic acids, cell debris, protein and exopolysaccharides which is collectively known as Extracellular polymeric substances (EPS) [54].

Enteric pathogens (Salmonella enterica and Escherichia coli) persist and resist to disinfection treatment by attaching themselves to the plant and by formation of biofilms as in figure 5.EPS of these 
bacterial biofilms also consists of amyloid curli and fimbriae. Curli/ amyloid fimbriae are the main protein components of such EPS as these help in adherence and colonization of the bacterial cells to plant surface [55]. O-antigen capsular proteins are also present in these enteric pathogens for biogenesis of biofilms by aiding in their attachment and subsequent colonization [51]. Similarly, flagellar rotation and functionality is also very important for biofilm formation, as flagella helps in initial attachment of bacteria to plant surface. The process of bacterial attachment is biphasic. In the first phase, attachment is weak, unspecific supported by electrostatic and hydrophobic interactions. In second phase the attachment is irreversible and strong (attachment to leaves, fruits, roots) called as firm attachment. This step involves cellulose formation. The cellulose part of EPS of biofilm serves as adherence factor for S. Enteric and E. coli.

Four categories of genes are involved in HEPs attachment, interaction and biofilm formation by HEPs $[\mathbf{5 7}, \mathbf{5 8}, \mathbf{5 9}, \mathbf{6 0}, \mathbf{6 1}]$ as synopsized in table3. These categories include genes for biogenesis of biofilm, chemotaxis and movement, genes involved in adhesion and genes for virulence properties [64]. Genes in bacteria that are involved in colonization of plants include bacterial cellulose synthase gene (bcs). It consists of bcsA, bcsB and bcsC genes, of which bcsA gene is present in Escherichia coli [53]. There are some genes that play role in biogenesis of bacterial motility organs like flagella. Similar genes i.e. fliN is present in K-12 strain of E.coli and fliC is present in Salmonella enterica. Similarly, agfAB is a gene present in $S$. enteric sero var enteritidis whose function is regulation and aggregation of fimbriae [53].

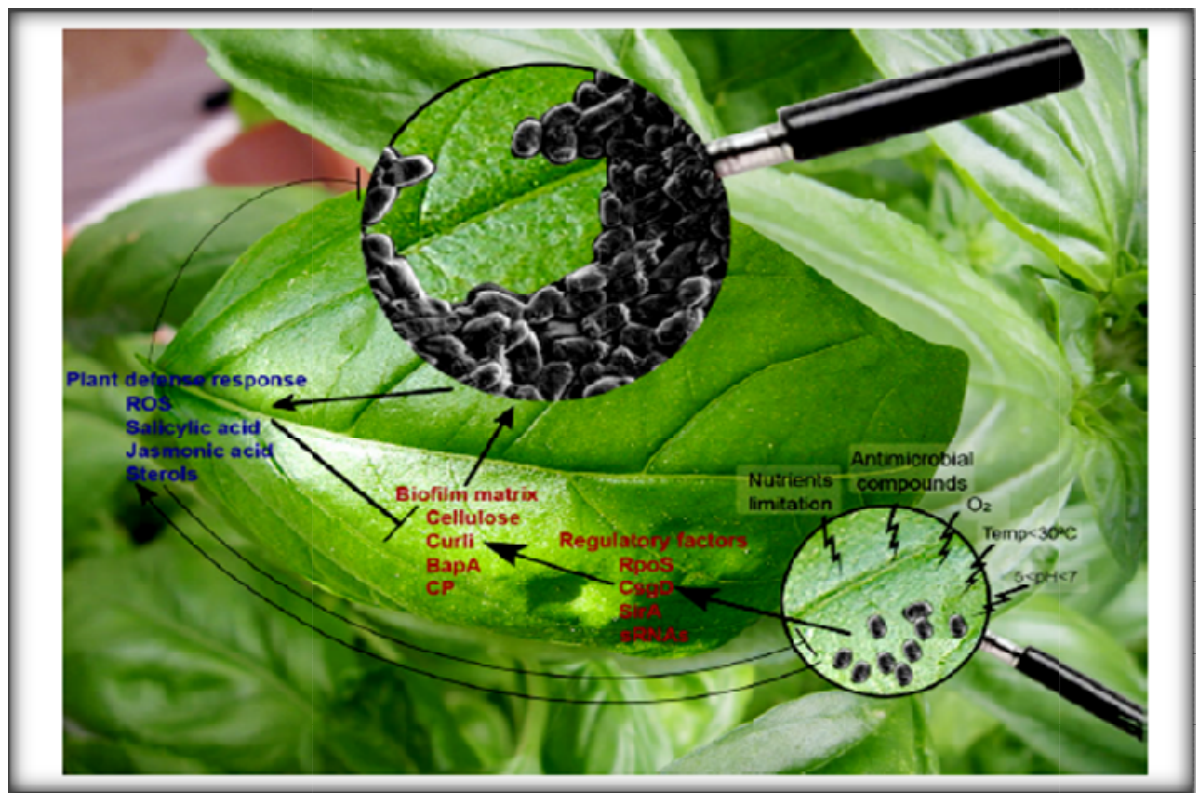

Figure 5: Formation of biofilm on leaf surface by Salmonella sp. 
Table 3: Genes entangled in interaction of enteric pathogen to plants

\begin{tabular}{|c|c|c|}
\hline ENTERIC PATHOGENS & GENES & PROPERTY OF GENES \\
\hline E. coli K-strain, E. coli $0157: H 7$ \&S. enteric & ycfR gene & $\begin{array}{l}\text { Development of biofilm, abiotic stress } \\
\text { forbearance, molecular colonization }\end{array}$ \\
\hline S. enteric sero varTyphimurium \& Saintpaul & ycfR gene & $\begin{array}{l}\text { Helpful to adhesion to leaves of spinach, } \\
\text { tomato, grapes. }\end{array}$ \\
\hline Salmonella species & sirA gene & Existence of pathogen on spinach species \\
\hline E.coli k-12 strain, O157:H7 & ybiM gene & Attachment to leaves of lettuce plants \\
\hline Salmonella enteric & fliC gene & Adherence to lettuce plants \\
\hline E. coli K-12 strain & fliN gene & $\begin{array}{c}\text { Biosynthesis of flagella, affinity to attach to } \\
\text { lettuce leaves }\end{array}$ \\
\hline Salmonella species & agf gene & Adhesion to lettuce plant \\
\hline E.coli strain & csg gene & Adhesion to seeds of alfalfa plant \\
\hline S. entericasero var Enteritidis & agfAB gene & Regulation and aggregation of fimbriae \\
\hline
\end{tabular}

Some additional factors also play important role in attachment of S.enterica and E.coli to plant surface. Plant surface consists of polysaccharide and glycoproteins such as pectin and cellulose. Studies showed that cellulose provide good factor for bacterial attachment. Nature and age of leaves determines the roughness of surface. Old leaves contaminated fast as compared to younger leaves. Some sites on which bacteria colonize and attack are epidermal cell wall junctions, stomata, trichomes, folding in veins and depression or beneath the cuticle. They are rich in nutrient and water and are protected from stress. Presence of trichomes on plant surface helps in attachment of enteric pathogens to various plant parts through open bases and stalks that are broken. Sites where microbial biofilms of HEPs can be formed are root surface, leaves, between intracellular spaces of plant tissue etc. More bacteria get attached to the lower leaf surface (abaxial side) than upper surface (adaxial side). Because on the lower surface, there is abundance of stomata and greater number of trichomes present and it has thin cuticle layer which is easier to invade. Also, lower leaf surface is less exposed to UV radiations and it has more availability of micronutrients secreted by plant. The bacteria once attached to the plant surface are protected from various factors of environmental stress i.e. UV rays, desiccation, temperature fluctuations, rainfall, disinfectants etc. [56].

EPSof biofilms also helps in the interaction of the one cell with another. Through quorum sensing molecules these enteric bacteria converse with each other. The last stage leads to formation of microcolonies that has multi-layered cells that resemble to 3D structure.Bacterial cells from the biofilms are able to survive the adverse environmental conditions as mentioned above.EPS formation is therefore very crucial for biofilm formation as it also acts as a physical barrier for bacterial cells. $S$. enterica and E. colihave been found to survive in the host plant and niches of the environment due to their ability to form biofilms. 
GENOMIC COMPARISON BETWEEN HEPs AND PLANTS

The techniques used in the study of colonization of plants by enteric pathogens include bioinformatics as well as molecular techniques. The genomic comparison between plants and enteric pathogens is done by alignment based search techniques and by using specific software and bioinformatics-based tools [54]. We can compare the genome of sequenced enteric bacteria with the plant genome using in silico genomic comparison technique [67]. To know the interaction between HEPs and plant we take an enteric bacteria containing protein with a known sequence and structure. By use of specific software we can assess if there is a possibility of their binding with a known receptor molecule of a plant. If they match and bind, then it is confirmed that enteric bacteria has the ability to interact with the plant. This is called as in silico genomic comparison [68]. The comparison can also be done by using RBH analysis (Reciprocal Best Hit) [69]. It is used to identify putative orthologous genes. This geneshares similar sequence and function with one or more genes of other organism [70]. In RBH, we take pair of gene sequences from two different genomes and by using sequence alignment method, best match is obtained and analysed. Organism containing putative orthologs means having RBH with identical sequence and they are determined to perform same biochemical function [71]. Protein sequence alignment is used to measure the similarity between 2 hosts by matching the structural similarity of their individual proteins [72]. Interactome level similarity is based on the protein-protein interaction between HEPs and host plant. It is also used to understand the genetic interactions. The protein-protein interaction graph (PPI graph) of one individual is being compared by other individual [73]. Distributional similarity is used to verify the similarity between Salmonella-protein pairs and plant-protein pairs [73]. Homology based transfer is for discovering interaction of the sequence similarity between plant and human enteric pathogen. This can be done by plant enteric orthologs in which the genes present in these two different species are evolved from same ancestral gene [73]. Another way is plantenteric pathogen homology in which they have same structural similarity but do not have common ancestry. BLAST is used for such protein sequence correlation and match the statistical significance. It is used to know evolutionary relationship $[\mathbf{7 4}, \mathbf{7 5}]$.

PLANT

DEFENSE

SYSTEM

\section{ACTIVATED BY HEPs}

Plants are not natural hosts for human pathogens. Despite this the enteric pathogens have the ability to invade and internalize plant tissues, although being non 
plant pathogenic.The immunity which gets activated when an enteric pathogen attempts to colonize or invade plants is referred to as plant innate immunity [76]. Two ways by which this immune response is triggered in plants have been classified as Pattern Triggered Immunity (PTI) and Effector Triggered Immunity (ETI) [77, 78].

There are some proteins and factors that are involved in the interaction of HEPs with plants. Microbe associated molecular pattern (MAMPs) and pathogen associated molecular pattern (PAMPs) are present in HEPs which have specific roles in recognising the pattern recognition receptors (PRRs) on plant surfaces. This process when a plant cell is encountered and bound by the HEPthrough MAMP/PAMP-PRR interaction mediates or triggers PTI as revealed in Figure 6 [76]. This triggered PTI activates MAPK cascade which further helps in expression of defence related genes in plant cells [79]. Products of such gene products involve various defence enzymes and many other factors leading to various physiological changes in plant to resist bacterial colonization. Flagellin plays a structural role in bacteria which helps the bacteria to attach as well as provide motility to bacteria. FLS2 (flagellin sensitive 2) receptor on plants recognises flagellin. E.coliand S. enterica also consists of the flagellin which mediates their colonization through FLS2 binding. Arabidopsis thaliana consists of fls 2 which is a Leucine rich repeat (LRR) region and also harbours elongation factor Tu receptor [80]. Both act as PRR for enteric bacterial PAMP/ MAMP flagellin, thereby contributing to resistance against bacterial pathogens. Few enteric pathogens also consist of LPS, curli, pili, flagella and peptidoglycans which are homologous to PAMPs of plant pathogenic bacteria. Curli can also function as PAMP and LPS present in S.typhimurium is a strong PAMP in tobacco plant [81].

Another way of inducing plant immune response is through secretion of effector molecules by pathogens that leads to ETI. Various research outcomes have shown that HEPs also secrete such effector molecules on colonizing their host plants. These effector molecules are injected into plant cell in order to take control of the cellular system of plant. These effector molecules are detected by NBB-LRR Proteins i.e. Nucleotide binding leucine rich repeat [82]. These NB-LRR proteins belong to class of resistance proteins that act as intracellular sensor proteins. This is followed by activation of resistance genes ( $\mathrm{R}$ genes) which causes ion-flux. It causes the potassium ion and hydroxide ion efflux and $\mathrm{H}+$ and $\mathrm{Ca} 2+$ ion influx. All such physiological changes result ina Hypersensitive Response (HR) [83]. HR 
then causes oxidative burst by the production of ROS (Reaction Oxygen Response) leading to cell death. ROS also triggers the lignin and callose deposition near the surrounding cells by which infection is not spread to the neighbouring cells [84]. The plant cell also responds in

the formation of nitric oxide, signalling molecules like salicylic acid (SA), jasmonate (JA) and ethylene. Biofilm formation is also inhibited by JA. In this way, pathogen infection is resisted by the plants and further infection spread is prevented.

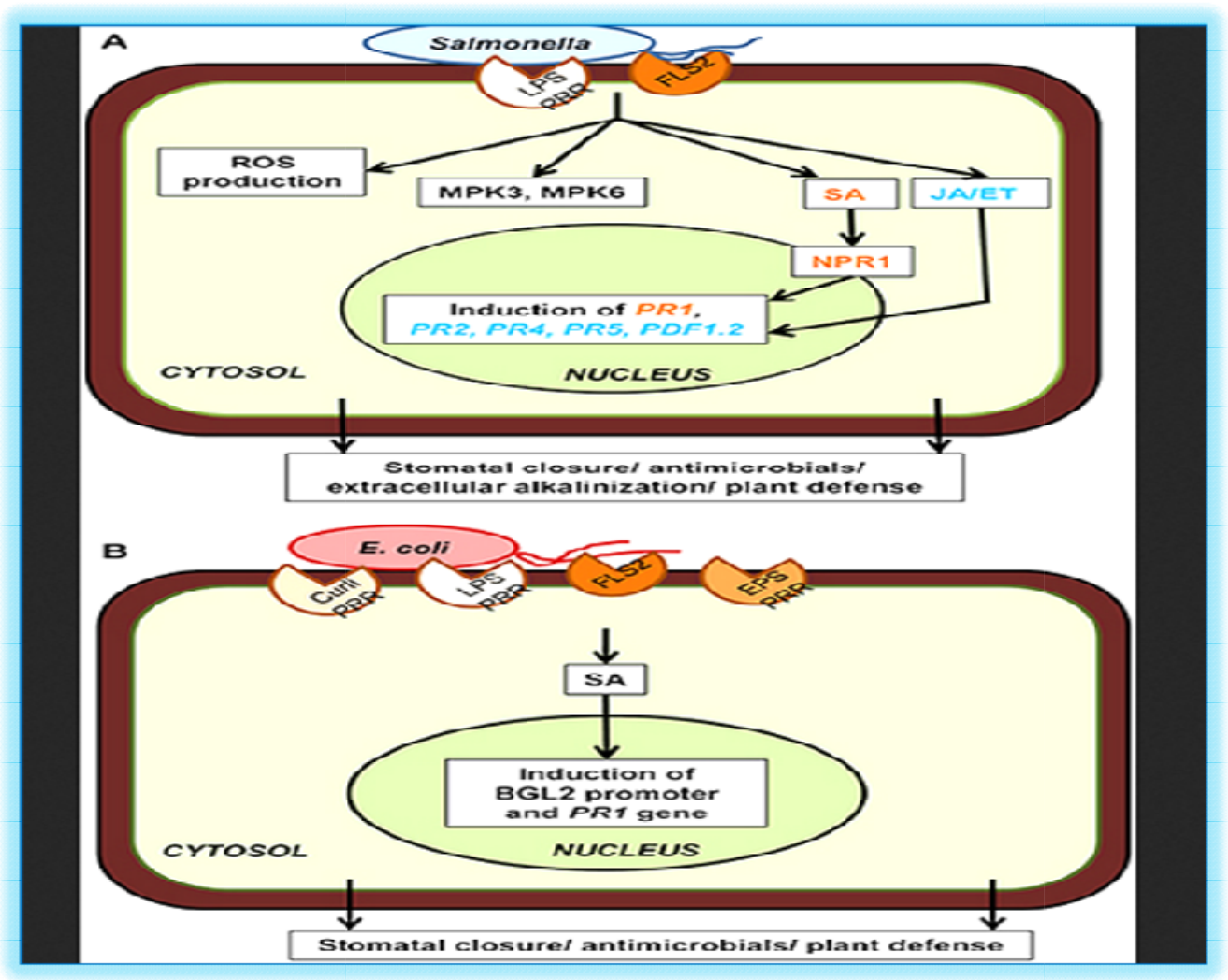

Figure 6: Development of plant innate immunity in response to HEPs

Plants also induce stomatal defence in response to HEPs [85]. When the flagellated enteric bacteria are detected by the plant, stomatal closure is induced to prevent the entry of HEPs as stomatal openings are the sites of gaseous exchange and nutrient leakage from plants [86]. For restricting bacterial colonization stomatal closure is used as plant defence mechanism. LPS (lipopolysaccharide) and flg22 (bacterial flagellin peptide) in E. coli have been found to mediate stomatal closure in a variety of host plants [85]. There are also other ways to stop the infection caused by enteric pathogens. The HRalso triggers different types of ETI leading toSystemic Acquired resistance (SAR) in plants to prevent any future colonization and invasion by same bacteria [87]. To achieve this, HR activates the 
transcription of phytoalexins and chitinases that degrade the cell wall of pathogen. HR also activates the hormonal signalling through SA, JA and ethylene as mentioned above.

Depending on the type and manner in which plant immune response is generated by a pathogen, HEPs can be categorised into two types:necrotrophic pathogens and biotrophic Pathogens. Nectropic pathogens induce the JA -pathway and biotrophic pathogens induce the SA- pathway. JApathway and SA-pathways induce the transcription of PR-genes i.e. pathogenesis related genes which are defence related genes of plant. PR-genes lead to expression of PR-proteins as discussed above [88]. In a nutshell, PTI is represented as first line of defence and ETI is represented as an amplified and accelerated response. Rapid response is the sum of PTI and ETI which together leads to HR.

\section{CONCLUSION}

Human enteric pathogens on plant parts is the linkage between pathogens present in the intestine to the plant's consumable parts. Plant serve as a host for the HEPs where it can live and thrive, flourish and nurture. It has been proved that enteric pathogens are adapted to the plant surface and they are also able to invade the plant parts.

It has been reported repeatedly that when HEPs come in contact of plants, they cause many food borne outbreaks. The most common enteric pathogens that cause foodborne outbreak are Escherichia coli, Salmonella enterica, Listeramono cytogenes, Campylobacter, Clostridium perfringens, Staphylococcus aureus. The consumption of contaminated fruits and vegetables with these pathogens lead to food borne illnesses. Tomato, spinach, lettuce, sprouts etc. are mostly get infected by enteric bacteria and cause food borne illness. Millions of people have been affected in United States, Canada, Europe, Asia due to food borne outbreaks over the last decade. Enteritis, diarrhoea, campylobacteriosis, listeriosis, salmonllosis and shigellosis are the major food borne outbreaks occurred all over the globe.

The different routes of enteric pathogens into the plants are: enteric pathogens get engulfed or attracted by the plant roots from the soil and through roots it gets transported through plants edible parts. It could also enter plant parts through manure into the agricultural field as farm yard dung based manure provides the best source of enteric pathogens. The water used for irrigation purpose can be infected with the livestock waste and untreated sewage water, both of which consist of noxious gases, have odour, and consist of harmful enteric pathogens. Also, the faecal matter of birds and animals consist of enteric 
pathogens. Human faecesalso contain enteric pathogens, so insects act as vectors in transferring such enteric pathogens from human faeces to plants. Seedscan also get contaminated by such insects and such seeds when dropped into the agricultural land infect the soil which again becomes entry route for contamination of other crops.

The unhealthy tissue of plant provides the best part for growth of enteric pathogen as it provides safety and macronutrients and micronutrients for its existence. The enteric pathogen when get associated with the plant's fruit, stem, flowers they affect the plant tissue through infiltration and colonization. Colonization process comprises of adhesion, development, existence and reproduction. The steps in the process of molecular colonization is adhesion i.e. the adherence of enteric bacteria to the lineament on surface of plant. Bacteria through their chemotactic response towards the root surface help them to move inside by their motility organs. The bacteria enter through the injured part or wounded part. These bacteria synthesize extracellular polymeric substance i.e. EPS that support the bacterial attachment to the surface of the plant and also help in other stages of colonization process. The structure of enteric bacteria such as fimbriae, flagella, surface of cell containing EPS help in attachment process. Root hairs, trichomes, wounds, leaf veins, leaf cut sections, shoot hydathodes are considered as the access sites for enteric bacteria. Enteric bacteria colonize the xylem and phloem tissue of the plant as well as root cortex through the apex of root i.e. root cap and root hairs. The intercellular spaces of the plant have rich source of nutrients containing various amino acids, carbohydrates, macronutrients and micronutrients that help the enteric bacteria in further colonization.

When enteric bacteria get attached to the plant surface it leads to the formation of biofilm. Biofilm formation is a key process that helps in existence of enteric bacteria on the plant surface. In response to these pathogens, plant also showsimmune response. Plant when acknowledge enteric pathogen on their surface, undergo various physiological changes in order to break the cycle of pathogen. Stomata, wax, cuticle, cell wall, trichomes etc. act as barrier for the invasion by enteric bacteria. Plant generates a response that is triggered by pathogen molecules and categorised as PTI, ETI or HR.

The various stages during which fresh produce is infected by HEPs are growing or expanding, reaping, postharvest handling, manufacturing and allocating or dividing. So, various measures should be taken to avoid the contamination of plants by HEPs. Ready to eat food, raw food etc. should be 
avoided. The fruits and vegetables should be washed and sanitized properly before consumption.Handling of food should be done properly. The foods should be cooked properly and raw and cooked food should be separated so that no cross contamination of pathogens occurs. Thus, by taking few safety measures in our day to day life we can avoid HEPs to contaminate plants and thus food borne outbreak can be controlled.

\section{ACKNOWLEDGEMENT}

Authors thank Amity Institute of Biotechnology, Amity University Uttar Pradesh to carry out this study and providing necessary support.

\section{REFERENCES}

[1] Glynis K, Martin Wu, and Richard L. Guerrant, "Enteric pathogens through life stages", frontiers in Cellular and Infection Microbiology, Volume 2, 2012.

[2] Mariat D., Firmesse O., Levenez F., Guimaraes V., Sokol H., Dore J., Corthier G., Furet J. P, "The Firmicutes/ Bacteroidetes ratio of the human microbiota changes with age”, BMC Microbiology, Volume 123, 2009.

[3] Su L., Shen L., Clayburgh D. R., Nalle S. C., Sullivan E. A., Meddings J. B., Abraham C., Turner J. R.,"Targeted epithelial tight junction dysfunction causes immune activation and contributes to development of experimental colitis”, Gastroenterology, Volume 136, 2009.

[4] Erickson, C, M., Liao, Jye-Yin, Payton, S, A.,Díaz, J. C., "Fate of enteric pathogens in different spinach cultivars cultivated in growth chamber and field systems", Food Quality and Safety, Volume 2, 2008.

[5] Itoh, Y., Sugita-Konishi, Y., Kasuga, F., Iwaki, M., Hara-Kudo, Y., Saito, N., Kumagai, S.K, "Enterohemorrhagic Escherichia coli $\mathrm{O} 157: \mathrm{H} 7$ present in radish sprouts", Applied and Environmental Microbiology, Volume 64, 1998.

[6] Islam M, Doyle M, Phatak SC, Millner P, Jiang X; "Persistence of Enterohemorrhagic Escherichia coli O157:H7 in Soil and on Leaf Lettuce and Parsley Grown in Fields Treated with Contaminated Manure Composts or Irrigation Water" Journal of Food Protection, Volume 67, 2004.

[7] Yvonne T.H.P. van Duynhoven, Marc-Alain Widdowson, Caroline M. de Jager, Teresa Fernandes, Sabine Neppelenbroek, Winette van den Brandhof, Wim J.B. Wannet, Jan A. van Kooij, Henk J.M. Rietveld, and Wilfrid van Pelt 
,Salmonella enterica serotype

Enteritidis phage type $4 \mathrm{~b}$ outbreak associated with bean sprouts", Emerging Infectious Diseases ,Volume 8, 2002 .

[8] Erickson, M. C, "Microbial Risks Associated with Cabbage, Carrots, Celery, Onions, and Deli Salads Made with These Produce Items", Comprehensive Reviews in Food Science and Food safety, Volume 9, 2010.

[9] Lim, J.-A., Lee, D. H., \& Heu, S, "The interaction of human enteric pathogens with plants", The Plant Pathology Journal, Volume 30, 2014.

[10] Bioinformatics Applications in Molecular Plant Pathology, frontiers.

[11] Thomas Bintsis, "Foodborne pathogens", AIMS Microbiology, Volume 3, 2017.

[12] Sockett, P. N., \& Rodgers, F. G., "Enteric and foodborne disease in children: A review of the influence of food- and environment-related risk factors", Paediatrics Child Health, Volume 6, 2001.

[13] Enteric Diseases Epidemiology Branch. (2018, June 15).

[14] Salmonella the most common cause of foodborne outbreaks in the European Union. (2019, December 12).

[15] Raquel M Callejón, M Isabel Rodriguez-Naranjo, Cristina

Ubeda, Ruth Hornedo-Ortega, M Carmen Garcia-Parrilla, Ana M Troncoso, "Reported Foodborne Outbreaks Due to Fresh Produce in United States and European Union: Trends and Causes", Foodborne Pathogen And Disease , Volume 12, 2015.

[16] State of Rhode Island: Department of Health.

[17] Maria T. Brandl, "Fitness of Human Enteric Pathogens on Plants and Implications for Food Safety", Annual Review of Phytopathology, Volume 44, 2006. [18] Natvig EE, Ingham SC, Ingham $\mathrm{BH}$, Cooperband LR, Teryl R Roper, "Salmonella entericaserovar Typhimurium and Escherichia coli contamination of root and leaf vegetables grown in soils with incorporated bovine manure", Applied Environmental Microbiology, Volume 69, 2002.

[19] Gagliardi JV, Karns JS, "Persistence of Escherichia coli O157:H7 in soil and on plant roots" Environmental Microbiology, Volume 4, 2002. 
[20] Williams AP, Avery LM, Killham K, Jones DLJ. "Survival of Escherichia coli $\mathrm{O} 157: \mathrm{H} 7$ in the rhizosphere of maize grown in waste-amended soil", Applied Microbiology, Volume 102, 2007.

[21] Cools D, Merckx R, Vlassak K, Verhaegen J, "Survival of $E$. coli and Enterococcus spp. derived from pig slurry in soils of different texture" Applied Soil Ecology, Volume 17, 2001.

[22] Solomon EB, Yaron S, Matthews KR, "Transmission of Escherichia coli $\mathrm{O} 157: \mathrm{H} 7$ from contaminated manure and irrigation water to lettuce plant tissue and its subsequent internalization" Applied Environmental Microbiology, Volume 72, 2002.

[23] Morris CE, Monier JM, "The ecological significance of biofilm formation by plant-associated bacteria" Annual Review Phytopathology, Volume 10, 2003.

[24] Stenström TA, "Bacterial hydrophobicity, an overall parameter for the measurement of adhesion potential to soil particles" Applied Environmental Microbiology, Volume 55, 1989.

[25] David, Cook, Nigel, Ruggeri, Sellwood, Jane, Bosch, "Virus hazards from food, water and other contaminated environment" FEMS Microbiology, Volume 36, 2012.

[26] Holden, Pritchard, L., \& Toth, I, "Colonization out with the colon: plants as an alternative environmental reservoir for human pathogenic enterobacteria", FEMS Microbiology Review, Volume 33, 2009.

[27] Bergsten G, Wullt B \& Svanborg C, "Escherichia coli, fimbriae, bacterial persistence and host response induction in the human urinary tract”, International Journal of Microbiology, Volume 295, 2005.

[28] Wilson IB, "Glycosylation of proteins in plants and invertebrates", Current Opinion of Structural Biology, Volume 12, 2002.

[29] Holden, Pritchard, L., \& Toth, I, "Colonization out with the colon: plants as an alternative environmental reservoir for human pathogenic enterobacteria.", FEMS Microbiology Review, Volume 33, 2019.

[30] Hueck CJ, “Type III protein secretion systems in bacterial pathogens of animals and plants" Microbiology and Molecular Biology Reviews, Volume 62, 1998. 
[31] Nougayrede JP, Fernandes PJ \& Donnenberg MS, "Adhesion of enteropathogenic Escherichia coli to host cells", Cellular Microbiology, Volume 5, 2003.

[32] Naylor SW, Roe AJ, Nart P, Spears K, Smith DG, Low JC \& Gally DL, "Escherichia coli O157:H7 forms attaching and effacing lesions at the terminal rectum of cattle and colonization requires the LEE4 operon", Europe PMC, Volume 151, 2005.

[33] Shaw RK, Berger CN, Feys B, Knutton S, Pallen MJ \& Frankel G, "Enterohemorrhagic Escherichia coli exploits EspA filaments for attachment to salad leaves", Applied and Environmental Biology, Volume 74, 2008.

[34] J, K. M. S. S. C. J. K.-S. "Techniques for Transferring Host-Pathogen Protein Interactions Knowledge to New Tasks", Frontiers in Microbiology, Volume 6, 2015.

[35] Jones DA \& Takemoto D, "Plant innate immunity - direct and indirect recognition of general and specific pathogen-associated molecules", Current opinion in Immunology, Volume 16, 2004.

[36] Caplan J, Padmanabhan M \& Dinesh-Kumar SP, "Plant NB-
LRR immune receptors: from recognition to transcriptional reprogramming" Cell Host and Microbe, Volume 3, 2008.

[37] Jones JDG \& Dangl JL, "The plant immune system" Nature, Volume 444, 2006.

[38] Ruiz-Albert J, Yu XJ, Beuzon CR, Blakey AN, Galyov EE \& Holden DW, "Complementary activities of SseJ and SifA regulate dynamics of the Salmonella typhimurium vacuolar membrane" Molecular Microbiology, Volume 44,2002.

[39] Iniguez AL, Dong Y, Carter HD, Ahmar BMM, Stone JM \&Triplett EW, "Regulation of enteric endophytic bacterial colonization by plant defences" Applied Environmental Biology, Volume 128, 2011.

[40] Liu, L., Sonbol, F., Huot, B., Gu, Y., Withers, J., Mwimba, M., Dong, X, "Salicylic acid receptors activate jasmonic acid signaling through a non-canonical pathway to promote effector-triggered immunity", Nature Communications, Volume 7, 2016.

[41] Betsuyaku, Shigeyuki, Shinpei, Takebayashi, Yumiko, Sakakibara, Nomura, "Salicylic Acid and Jasmonic Acid Pathways are Activated in Spatially Different 
Domains Around the Infection Site

During Effector-Triggered Immunity in Arabidopsis thaliana" Plant cell Pathology, Volume 59, 2018.

[42] Ruan, J., Zhou, Y., Zhou, M., Yan, J., Khurshid, M., Weng, W., Zhang, K, "Jasmonic Acid Signaling Pathway in Plants", International journal of molecular sciences, Volume 20, 2019.

[43] Tan M., White, A., Rahman, S., \& Dykes, "Role of Fimbriae, Flagella and Cellulose on the Attachment of Salmonella typhimurium ATCC 14028 to Plant Cell Wall Models" PLOS ONE, Volume 137, 2006.

[44] Barak, J., \& Lara C. Kramer, L. "Colonization of Tomato Plants by Salmonella enterica Is Cultivar Dependent, and Type 1 Trichomes Are Preferred Colonization Sites", Applied and Environmental Microbiology, Volume 77, 2011.

[45] Annette Angus, "Biofilm Formation in the Rhizosphere: Multispecies Interactions and Implications for Plant Growth" Wiley Online Library, Volume 66, 2013.

[46] Rudrappa, Biedrzycki, \& L., M, "Causes and consequences of plant-associated biofilms", FEMS Microbiology Ecology, Volume 64, 2008.
[47] Wright, K., Crozier, L., Marshall, J., Merget, B., Holmes, A., \& Holden, N. "Differences in internalization and growth of Escherichia coli O157:H7 within the apoplast of edible plants, spinach and lettuce, compared with the model species Nicotiana benthamiana", Microbial Biotechnology, Volume 10, 2017.

[48] Carmen Gomes, Paulo Da Silva, Rosana G Moreira, Elena CastellPerez, E Ann Ellis, Michael Pendleton, "Understanding E. Coli Internalization in Lettuce Leaves for Optimization of Irradiation Treatment" International Journal of Food Microbiology, Volume 135, 2009.

[49] YuliaKroupitski, Rachel Gollop, Eduard Belausov, Riky Pinto and Shlomo Sela (Saldinger) "Salmonella enterica Growth Conditions Influence Lettuce Leaf Internalization", Frontiers Microbiology, Volume 639, 2019.

[50] Jeri D. Barak,Lara C. Kramer, and Ling-yunHao, "Colonization of Tomato Plants by Salmonella enterica Is Cultivar Dependent, and Type 1 Trichomes Are Preferred Colonization Sites" Applied and Environmental Biology, Volume 77, 2010. 
[51] Callaway, T., Carroll, J., Arthington, J., Pratt, C., Edrington, T., Anderson, R., Galyean, M., Ricke, S., Crandall, P. and Nisbet, D, "Citrus Products Decrease Growth of E. coli O157:H7 And Salmonella typhimurium In Pure Culture And In Fermentation With Mixed Ruminal Microorganisms In Vitro", Foodborne Pathogen and Disease, Volume 5, 2020.

[52] Aug. B Shawn Eblen, Mark O Walderhaug, Sharon EdelsonMammel, Stuart J Chirtel, Antonio De Jesus, Robert I Merker, Robert L Buchanan, Arthur J Miller, "Potential for Internalization, Growth, and Survival of Salmonella and Escherichia Coli O157:H7 in Oranges", Journal of food protection, Volume 67, 2004.

[53] U; Y. S. R, "Biofilm Formation by Enteric Pathogens and Its Role in Plant Colonization and Persistence", Microbial Biotechnology, Volume 7, 2014.

[54] Holden, Pritchard, L., \& Toth, I, "Colonization out with the colon: plants as an alternative environmental reservoir for human pathogenic enterobacteria", FEMS Microbiology Review, Volume 33, 2009.
[55] Heather L Tyler, Eric W Triplett, "Plants as a Habitat for Beneficial and/or Human Pathogenic Bacteria", Annual Review of Phytopathology, Volume 46, 2008.

[56] Yaron, S., \& Römling, U, "Biofilm formation by enteric pathogens and its role in plant colonization and persistence" Microbial Biotechnology, Volume 7, 2014.

[57] Deng, K, S Wang, X Rui, W Zhang, and ML Tortorello, "Functional analysis of ycfR and ycfQ in Escherichia coli $\mathrm{O} 157: \mathrm{H} 7$ linked to outbreaks of illness associated with fresh produce" Applied and Environmental Microbiology, Volume 77, 2011.

[58] Fink, RC, EP Black, Z Hou, M Sugawara, MJ Sadowsky, and F Diez-Gonzalez. "Transcriptional responses of Escherichia coli K-12 and $\mathrm{O} 157: \mathrm{H} 7$ associated with lettuce leaves", Applied and Environmental Biology, Volume 78, 2012.

[59] Kroupitski, Y, D Golberg, E Belausov, R Pinto, D Swartzberg, D Granot and S Sela, "Internalization of Salmonella enterica in leaves is induced by light and involves chemotaxis and penetration through open stomata" 
Applied and Environmental

Microbiology, Volume 75, 2009.

[60] Macarisin, D, J Patel, G Bauchan, JA Giron, and VK Sharma, "Role of curli and cellulose expression in adherence of Escherichia coli O157:H7 to spinach leaves", Foodborne Pathogen and Disease, Volume 9, 2012.

[61] Kyle, J, CT Parker, D Goudeau, and M Brandl, "Transcriptome analysis of Escherichia coli O157:H7 exposed to lysates of lettuce leaves", Applied andEnvironmental Microbiology, Volume 2009.

[62] Salazar, JK, K Deng, ML Tortorello, MT Brandl, H Wang, and W Zhang, "Genes ycfR, sirA and yigG contribute to the surface attachment of Salmonella enteric typhimurium and Saintpaul to fresh produce", PLOS One, Volume 8, 2013.

[63] Uhlich, GA, PH Cooke, and EB Solomon, "Analyses of the reddry-rough phenotype of an Escherichia coli O157:H7 strain and its role in biofilm formation and resistance to antibacterial agents", Applied and Environmental Biotechnology, Volume 72, 2006.
[64] Enteric Pathogen-Plant Interactions: Molecular Connections Leading to Colonization and Growth and Implications for Food Safety.

[65] Taglialegna, A., Lasa, I., \& Valle, $\mathrm{J}$, “Amyloid Structures as Biofilm Matrix Scaffolds", Journal of Bacteriology, Volume 198, 2016.

[66] Barak, J.D., Jahn, C.E., Gibson, D.L., and Charkowski, A.O, "The role of cellulose and $\mathrm{O}$-antigen capsule in the colonization of plants by Salmonella enterica" Molecular Plant Microbe Interaction, Volume 20, 2007.

[67] Andrea, López, \& Camilo, "In Silico Genome Comparison and Distribution Analysis of Simple Sequences Repeats in Cassava", International Journal of Genomics, Volume 2014.

[68] Punta, M., \& Ofran, Y, "The rough guide to in silico function prediction, or how to use sequence and structure information to predict protein function" PLOS Computational Biology, Volume 4, 2008.

[69] Moreno-Hagelsieb G \& Latimer $\mathrm{K}$, "Choosing BLAST options for better detection of orthologs as reciprocal best hits" Bioinformatics (Oxford, England), Volume 24, 2008. 
[70] Pritchard L, White JA, Birch PRJ \& Toth IK, "Genome Diagram: a python package for the visualization of large-scale genomic data" Bioinformatics, Volume 22, 2006.

[71] Cole BJ, Feltcher ME, Waters RJ, Wetmore KM, Mucyn TS, Ryan EM, et al, "Genome-wide identification of bacterial plant colonization genes", PLOS Biology, Volume 10, 2017.

[72] Toth IK, Pritchard L \& Birch PR, "Comparative genomics reveals what makes anenterobacterial plant pathogen”, Annual ReviewOf Phytopathology, Volume 44, 2006.

[73] J, K. M. S. S. C. J. K.-S. (n.d.). Techniques for Transferring HostPathogen Protein Interactions Knowledge to New Tasks.

[74] Rasheed, F., Markgren, J., Hedenqvist, M., \& Johansson, E. "Modeling to Understand Plant Protein Structure-Function Relationships-Implications for Seed Storage Proteins" Molecules (Basel, Switzerland), Volume 25, 2020.

[75] Kshirsagar, Sylvia, Carbonell, \& Judith, "Techniques for transferring host-pathogen protein interactions knowledge to new tasks", Frontiers in Microbiology, Volume 6, 2015.

[76] JL; J. J. D. D. “The Plant Immune System", Nature, Volume 444, 2006.

[77] X; S. S. H. D, "How Do Plants Achieve Immunity? Defence without Specialized Immune Cells" Nature's Review, Immunology, Volume 12, 2012.

[78] Yoji Kawano, Letian Chen, "The Function of Rac Small GTPase and Associated Proteins in Rice Innate Immunity", Springer link, Volume 3, 2010.

[79] Kazan, K., \& Lyons, R, "Intervention of Phytohormone Pathways by Pathogen Effectors", The Plant Cell, Volume 6, 2014.

[80] Iniguez AL; DongY; Carter HD; Ahmer BM; Stone JM; Triplett EW, "Regulation of Enteric Endophytic Bacterial Colonization by Plant Defences", International Society for Molecular PlantMicrobe Interactions, Volume 10, 2007.

[81] Natali Shirron and Soma Yaron, "Active suppression of early immune response in tobacco by the human pathogen Salmonella typhimurium", PLOS one, Volume 10, 2006. 
[82] Irieda, H., Inoue, Y., Mori, M., Yamada, K., Oshikawa, Y., Saitoh, H, Takano, Y. "Conserved fungal effector suppresses PAMPtriggered immunity by targeting plant immune kinases", Proc Natl AcadSci USA, Volume 116, 2018.

[83] Balint-Kurti, P, "The plant hypersensitive response: concepts, control and consequences", Molecular Plant Pathology, Volume 20, 2015.

[84] Melotto, M., Panchal, S., \& Roy, D, "Plant innate immunity against human bacterial pathogens" frontiers in Microbiology, Volume 5, 2014.

[85] Melotto M, Underwood W, KoczanJ, NomuraK, He SY, "Plant Stomata Function in Innate Immunity against Bacterial Invasion", Cell, Volume 125, 2006.

[86] SY, Z. W. M. M. H, "Plant Stomata: A Checkpoint of Host Immunity and Pathogen Virulence", Current Opinion in Biotechnology.

[87] Grennan, A. K, "Plant Response to Bacterial Pathogens. Overlap between Innate and Gene-forGene Defense Response", Plant Physiology, Volume 10, 2010.
[88] Li, N., Han, X., Feng, D., Yuan, D., \& Huang, L.-J, "Signalling Crosstalk between Salicylic Acid and Ethylene/Jasmonate in Plant Defense: Do We Understand What They Are Whispering?" International Journal of Molecular Sciences, Volume 4, 2019. 